\title{
PEMBELAJARAN OPTIKA GEOMETRI MELALUI PROBLEM BASED LEARNING (PBL) DITINJAU DARI KEMAMPUAN BERPIKIR KRITIS SISWA DAN KEMAMPUAN BERPIKIR KREATIF SISWA SMA KELAS X TAHUN 2014/2015
}

\author{
Elly Eka Wahyudi ${ }^{1}$, Nonoh Siti Aminah ${ }^{2}$ dan Sukarmin ${ }^{3}$ \\ ${ }^{1}$ Program Studi Magister Pendidikan Sains FKIP Universitas Sebelas Maret \\ Surakarta, 57126, Indonesia \\ ellyekawahyudi@student.uns.ac.id \\ ${ }^{2}$ Program Studi Magister Pendidikan Sains FKIP Universitas Sebelas Maret \\ Surakarta, 57126, Indonesia \\ nonoh_nst@staff.uns.ac.id \\ ${ }^{3}$ Program Studi Magister Pendidikan Sains FKIP Universitas Sebelas Maret \\ Surakarta, 57126, Indonesia \\ sukarmin67@staff.uns.ac.id
}

\begin{abstract}
Abstrak
Penelitian ini bertujuan untuk mengetahui pengaruh dan interaksi penggunaan model Problem Based Learning $(P B L)$ melalui metode eksperimen dan metode demonstrasi ditinjau dari kemampuan berpikir kritis dan kemampuan berpikir kreatif terhadap hasil belajar. Desain penelitian ini adalah eksperimen. Populasi dari penelitian ini siswa SMA Negeri 4 Madiun kelas X tahun pelajaran 2014/2015. Sampel diambil dengan teknik Cluster Random Sampling, sampel terdiri dari 2 kelas yaitu kelas X B dan X C. Kelas X B diberi pembelajaran dengan Problem Based Learning (PBL) menggunakan metode eksperimen, sedangkan X C diberi pembelajaran Problem Based Learning (PBL) dengan metode demonstrasi. Data hasil belajar kognitif, kemampuan berpikir kritis dan kemampuan berpikir kreatif diambil menggunakan instrumen tes, sedangkan data hasil belajar afektif dan psikomotor menggunakan lembar observasi. Data dianalisis menggunakan analisis variansi (anava) tiga jalan dan dilanjutkan dengan uji Compare Means. Hasil penelitian menunjukkan: 1) tidak terdapat pengaruh pembelajaran Fisika melalui Problem Based Learning (PBL) menggunakan metode eksperimen dan metode demonstrasi terhadap hasil belajar; 2) tidak terdapat pengaruh kemampuan berpikir kritis terhadap hasil belajar kognitif, afektif, dan psikomotor; 3) terdapat pengaruh kemampuan berpikir kreatif terhadap hasil belajar kognitif, namun tidak terdapat perbedaan pengaruh terhadap hasil belajar afektif dan psikomotor; 4) tidak terdapat pengaruh interaksi pembelajaran Fisika Problem Based Learning (PBL) mengunakan metode eksperimen dan metode demonstrasi dengan kemampuan berpikir kritis terhadap hasil belajar; 5) tidak terdapat pengaruh interaksi pembelajaran Fisika Problem Based Learning $(P B L)$ menggunakan metode eksperimen dan metode demonstarsi dengan kemampuan berpikir kreatif terhadap hasil belajar; 6) tidak terdapat pengaruh interaksi kemampuan berpikir kritis dan kemampuan berpikir kreatif terhadap hasil belajar; 7) tidak terdapat pengaruh interaksi pembelajaran Fisika Problem Based Learning (PBL) menggunakan metode eksperimen dan metode demonstrasi, kemampuan berpikir kritis, dan kreatif terhadap hasil belajar.
\end{abstract}

Kata Kunci: Problem Based Learning (PBL), metode eksperimen, metode demonstrasi, kemampuan berpikir kritis, kemampuan berpikir kreatif.

\section{Pendahuluan}

Fisika adalah ilmu pengetahuan yang berkaitan dengan penemuan dan pemahaman mendasar hukum-hukum yang menggerakkan materi, energi, ruang dan waktu. Karenanya sebagian siswa merasa takut, dan tertekan dalam memahami konsep-konsep dan rumusrumus Fisika yang dianggap sangat sulit (Sugiarti, 2005).

Pembelajaran merupakan interaksi antara guru dan siswa beserta unsur yang ada di dalamnya. Guru merupakan faktor yang 
paling dominan yang menentukan kualitas pembelajaran. Kualitas pembelajaran yang baik, tentu akan menghasilkan hasil belajar yang baik pula. Menurut Rusman (2012), dalam sistem pembelajaran guru dituntut untuk mampu memilih metode pembelajaran yang tepat, mampu memilih dan menggunakan fasilitas pembelajaran, mampu memilih dan menggunakan alat evaluasi, mampu mengelola pembelajaran di kelas maupun di laboratorium, menguasai materi, dan memahami karakter siswa. Salah satu tuntutan guru adalah mampu memilih metode pembelajaran yang tepat untuk mengajar. Apabila metode pembelajaran yang digunakan guru itu tepat maka pencapaian tujuan pembelajaran akan mudah tercapai, sehingga nilai ketuntasan siswa akan meningkat.

Kemampuan siswa yang berbeda-beda menjadi tantangan bagi guru agar melakukan atau menerapkan model yang sesuai dengan kemampuan dan keadaaan siswa sehingga dalam pembelajaran tersebut menjadi efektif. Penerapan pembelajaran yang selama ini dilakukan oleh seorang guru dalam menyampaikan materi-materi Fisika adalah metode konvensional yang cenderung searah. Dalam pembelajarannya siswa cenderung pasif karena pembelajaran berpusat pada guru karena itu perlu adanya model dalam pembelajaran Fisika agar siswa lebih mudah dalam belajar Fisika dan menjadikan pembelajaran menjadi lebih menyenangkan.

Kegiatan belajar siswa di sekolah bertujuan membawa siswa menuju ke keadaan yang lebih baik dari segi kognitif, afektif dan psikomotor yang bersifat permanen. Hasil dari pembelajaran yang bersifat permanen membuat guru harus benar-benar mempersiapkan pembelajaran dengan baik, agar tidak terjadi kesalahan konsep. Konsep pada pembelajaran Fisika di SMA perlu ditanamkan dengan kuat, agar siswa tidak mengalami kesulitan ketika berada pada jenjang yang lebih tinggi. Pembelajaran Fisika lebih baik dikemas dalam pembelajaran yang menekankan pada konsep dan melatih siswa berpikir kreatif dan bersifat kritis, sehingga siswa bisa menjadi tertarik dalam mempelajari Fisika.
Salah satu model pembelajaran sebagai alternatif agar belajar Fisika menjadi mudah dan menyenangkan adalah dengan model pembelajaran PBL. Adapun tujuan PBL menurut Rusman (2010), yaitu penguasaan isi belajar dari disiplin heuristik dan pengembangan keterampilan pemecahan masalah. PBL juga berhubungan dengan belajar tentang kehidupan yang lebih luas (lifewide learning), keterampilan memaknai informasi, kolaborasi dan belajar tim, dan keterampilan berpikit reflektif dan evaluatif. Trianto (2010), menyatakan bahwa tujuan PBL yaitu membantu siswa mengembangkan keterampilan berpikir dan keterampilan mengatasi masalah, belajar peranan orang dewasa yang autentik dan menjadi pembelajar yang mandiri.

PBL merupakan model belajar yang menggunakan masalah sebagai langkah awal dalam mengumpulkan dan mengintegrasikan pengetahuan baru. Siswa diberikan permasalahan pada awal pelaksanaan pembelajaran oleh guru, selanjutnya selama pelaksanaan pembelajaran siswa memecahkannya yang akhirnya mengintegrasikan pengetahuan ke dalam bentuk laporan. PBL dapat memberikan pemahaman pada siswa lebih mendalam dalam segi analisis teori maupun praktik.

Masalah-masalah tersebut dapat diselesaikan dengan cara guru harus mengetahui kemampuan awal masing-masing siswa. Kemampuan awal siswa dapat diambil dari nilai ulangan materi sebelumnya, untuk mengetahui lebih dalam masing-masing kemampuan siswa guru dapat menggunakan tes kemampuan berpikir yang sesuai dengan pembelajaran Fisika seperti kemampuan berpikir kritis dan berpikir kreatif. Dengan mengetahui kemampuan siswa terlebih dahulu dapat membantu ketercapaian tujuan pembelajaran.

Berpikir kreatif mempunyai kaitan yang erat denga kreativitas. Menurut Munandar (2002), kreativitas merupakan kemampuan umum untuk menciptakan sesuatu yang baru, sebgai kemampuan untuk member gagasan-gagasan baru yang dapat diterapakan dalam pemecahan masalah atau sebgai 
kemampuan untuk melihat hubunganhubungan baru antara unsur-unsur yang sudah ada sebelumnya. Wijaya (2007), juga menjelaskan bahwa berpikir kreatif adalah kegiatan menciptakan model-model tertentu, dengan maksud untuk menambah agar lebih kaya dan menciptakan yang baru. Berdasarkan pendapat-pendapat tersebut, maka berpikir kreatif dapat diartikan yaitu berpikir secara logis dan divergen untuk menghasilkan sesuatu yang baru.

Kemampuan berpikir kritis yang baik dapat membentuk sikap dan perilaku yang rasional. Jadi, meningkatkan kemampuan berpikir kritis sangat perlu dan urgen untuk dikembangkan terlebih pada masa sekarang yang penuh dengan permasalahanpermasalahan atau tantangan-tatangan hidup. Dengan demikian, tidak berlebihan apabila disektor pendidikan mengharuskan untuk mempersiapkan siswa atau generasi penerus bangsa untuk menjadi pemikir-pemikir yang kritis, jujur dan bermartabat, sehingga mampu menghadapi berbagai tantangan dan dapat bertahan hidup secara manusawi dengan penuh rasa percaya diri. Hal ini sesuai dengan tujuan umum dijenjang persekolahan yaitu mempersiapkan siswa agar sanggup menghadapi perubahan keadaan di dalam kehidupan dan dunia yang selalu berubah dan berkembang melalui latihan bertindak atas dasar pemikiran secara logis, kritis, cermat, jujur, efektif dan dapat menggunakan pola piker matematis dalam kehidupan sehari-hari dan dalam mempelajari sebagai ilmu pengetahuan (Depdiknas, 2004).

Guru mempersiapkan pembelajaran dengan metode atau model yang disesuaikan dengan materi pembelajaran Fisika. Model dan metode yang dipilih ditekankan dapat memberi pembelajaran yang bermakna pada siswa, sehingga dapat membantu ingatan siswa dalam jangka waktu yang panjang. Pembelajaran Fisika yang materinya bersifat abstrak dan susah dipahami dikemas dengan pembelajaran yang menyenangkan. Dengan menggunakan model PBL siswa diberi stimulus permasalahan sebelum memulai pembelajaran, dengan permasalahan yang diberikan guru siswa dapat langsung mengarahkan pemikiran kreatifnya pada materi yang akan diajarkan. Permasalahan yang diberikan oleh guru, dan siswa memberi asumsi-asumsi jawaban dari permasalahan tersebut dapat dibuktikan dengan suatu eksperimen ataupun demonstrasi.

Menurut Sudirman (1991), metode eksperimen adalah cara penyajian pelajaran, siswa melakukan percobaan dengan mengalami dan membuktikan sendiri sesuatu yang dipelajari. Menurut Ali (2000), menyatakan bahwa metode eksperimen adalah percobaan tentang sesuatu. Dalam hal ini setiap siswa bekerja sendiri-sendiri. Pelaksanaan lebih mempelajari hasil belajar, karena setiap siswa mengalami dan melakukan kegiatan percobaan. Sedangkan menurut Sudjana (2000), mengemukakan bahwa metode eksperimen adalah metode mengajar yang sangat efektif sebab membantu siswa untuk mencari jawaban dengan usaha sendiri berdasarkan fakta (data) yang benar.

Sesuai ulasan yang dinyatakan dalam metode eksperimen di atas bahwa metode eksperimen adalah suatu cara penyampaian pengajaran dengan melakukan kegiatan percobaan untuk menemukan sendiri yang dipelajari. Pada penelitian, kegiatan eksperimen mengacu pada Lembar Kerja Siswa (LKS) yag dibuat. Sesuai dengan karakteristik metode eksperimen yaitu LKS harus terdapat variable-variabel yang diidentifikasi, yang meliputi variabel manipulasi, variabel respon, dan variabel kontrol.

Metode demonstrasi adalah pertunjukan tentang proses terjadinya suatu peristiwa atau benda sampai pada penampilan tingkah laku yang dicontohkan agar dapat diketahui dan dipahami oleh peserta didik secara nyata atau tiruannya (Sagala, 2007). Metode demonstrasi adalah metode mengajar dengan cara memperagakan barang, kejadian, aturan, dan urutan melakukan suatu kegiatan baik secara langsung maupun melalui penggunaan media pengajaran yang relevan dengan pokok bahasan atau materi yang sedang disajikan (Syah, 2010). Sementara menurut Djamarah (2000), bahwa metode demonstrasi adalah metode yang digunakan untuk memperlihatkan sesuatu proses atau cara 
kerja suatu benda yang berkenaan dengan bahan pelajaran. Dengan metode demonstrasi peserta didik berkesempatan mengembangkan kemampuan mengamati segala benda yang sedang terlibat dalam proses serta dapat mengambil kesimpulan-kesimpulan yang diharapkan. Tujuan pengajaran menggunakan metode demonstrasi adalah untuk memperlihatkan proses terjadinya suatu peristiwa sesuai materi ajar, cara pencapaiannya, dan kemudahan untuk dipahami oleh siswa dalam pengajaran kelas. Metode demonstrasi mempunyai beberapa kelebihan dan kelekurangan. Manfaat psikologis dari metode demonstrasi adalah perhatian siswa dapat lebih dipusatkan, proses belajar siswa lebih terarah pada materi yang sedang dipelajari, pengalaman dan kesan sebagai hasil pembelajaran lebih melekat dalam diri siswa.

Penggunaan metode eksperimen dan metode demonstrasi siswa diharapkan menemukan sendiri konsep dari materi Fisika yang diajarkan. Dengan mengalami proses eksperimen ataupun pembuatan demonstrasi siswa dapat mengembangkan pemikiran mereka secara kritis ataupun kreatif, selain itu juga dapat menjadikan pembelajaran tersebut menjadi bermakna dan diingat dalam jangka waktu yang panjang.

Mata pelajaran Fisika didapat bahwa materi Optika Geometri pada bagian materi Cahaya memiliki nilai yang rendah ditingkat Nasional yaitu 70,81. Hal itu membuktikan bahwa mata pelajaran Fisika pada materi Optika Geometri merupakan materi yang sulit bagi siswa. Hasil pengamatan yang dilakukan saat pembelajaran berlangsung diperoleh penyebab hasil UN Fisika rendah yaitu kurang kooperatifnya siswa dalam mengikuti pelajaran, siswa cenderung ada yang tidak memperhatikan saat pelajaran, masa bodoh, dan kurangnya motivasi untuk belajar. Sikap siswa yang seperti itu sangat mempengaruhi ketidaktercapaian tujuan pembelajaran dan menjadikan siswa mengalami kegagalan dalam belajar.

Materi Optika Geometri merupakan salah satu materi yang diajarkan dalam Fisika di jenjang SMA, dalam materi ini banyak terdapat teori yang harus dibuktikan. Siswa harus mampu untuk membuktikan teori tersebut baik dengan matematis ataupun percobaan. Banyak siswa kesulitan untuk mempelajari materi Optika Geometri karena materi sulit untuk dipahami dan perlu eksperimen yang benar untuk memahaminya, terbukti dengan didapat data nilai ulangan dua tahun terakhir siswa kelas X SMA N 4 Madiun tahun pelajaran 2012-2013 dengan KKM 75 siswa yang tuntas sebanyak 5 siswa dan yang tidak tuntas sebanyak 25 siswa, serta pada tahun pelajaran 2013-2014 dengan KKM 75 siswa yang tuntas sebanyak 7 siswa sedangkan siswa yang tidak tuntas sebanyak 24 siswa.

Hasil tes formatif pada materi Optika Geometri membuktikan bahwa materinya sulit karena banyak siswa yang tidak tuntas. Materi Optika Geometri yang bersifat abstrak membuat siswa kesulitan untuk memahaminya, dengan menggunakan PBL yang dikembangkan dengan metode ekperimen dan metode demonstrasi ditinjau dari kemampuan berpikir kritis dan kemampuan berpikir kreatif siswa dapat mengalami sendiri proses pembelajaran menuju konsep. Siswa diharapkan dapat mencapai tujuan pembelajaran. Sehingga membuat siswa lebih antusias dalam pembelajaran dan dapat memperbaiki nilai pada mata pelajaran Fisika khususnya materi Optika Geometri.

Kemampuan berpikir kritis dan kemampuan berpikir kreatif dalam penelitian ini dibatasi pada kategori tinggi dan rendah. Hasil belajar yang akan diteliti meliputi aspek kognitif, afektif dan psikomotor yang diharapkan mampu untuk mengetahui pengaruh secara menyeluruh terhadap perubahan hasil belajar tersebut. PBL merupakan bagian dalam pembelajaran kontekstual, dengan guru memberikan suatu permasalahan untuk dipecahkan siswa. Dengan ungkapan lain, pembelajaran berbasis pada masalah yang relevan dengan materi yang dipelajari. Dalam hal ini guru menjelaskan tujuan penting yang dibutuhkan, memotivasi siswa agar terlibat secara aktif dalam pemecahan masalah yang dipilih, serta membantu siswa dalam mendefinisikan dan mengorganisasikan tugas belajar yang 
berhubungan dengan masalah tersebut. Setelah itu, guru mendorong siswa untuk mengumpulkan informasi yang sesuai, melaksanakan eksperimen guna mendapatkan penjelasan dan pemecahan masalah, serta membantu siswa dalam merencanakan dan menyiapkan karya yang sesuai, seperti laporan. Kegiatan selanjutnya ialah mengevaluasi hasil belajar tentang materi yang telah dipelajari atau menyusun kelompok presentasi hasil kerja.

PBL tidak dirancang untuk membantu guru memberikan informasi sebanyakbanyaknya kepada siswa. PBL antara lain bertujuan membantu siswa mengembagkan keterampilan berpikir dan pemecahan masalah. Model tersebut bercirikan penggunaan masalah kehidupan nyata sebagai sesuatu yang harus dipelajari oleh siswa untuk melatih dan meningkatkan keterampilan berpikir kritis siswa sekaligus pemecahan masalah, serta mendapatkan pengetahuan konsep-konsep penting.

Teori yang dikembangkan oleh Piaget dalam Putra (2013), mengemukakan bahwa siswa dalam segala usia sacara aktif terlibat dalam proses perolehan informasi dan membangun pengetahuan sendiri. Pada hakikatnya, pedagogi yang baik melibatkan siswa dalam situasi yang memberi kesempatan kepadanya untuk melakukan percobaan sendiri, mencoba memanipulasi tanda-tanda dan simbol-simbol, bertanya dan menemukan sendiri jawabannya, mencocokan yang dilihat pada waktu lainnya, serta membandingkan temuannya dengan temuan siswa yang lain. Sebenarnya siswa akan mendapatkan pengetahuan dan keterampilan yang dibutuhkan atas masalah tersebut.

Menurut Djamarah (2000), metode eksperimen adalah cara penyajian pelajaran saat siswa melakukan percobaan dengan mengalami dan membuktikan sendiri sesuatu yang dipelajarinya. Lain halnya dengan Roestiyah (2001), yang beranggapan bahwa metode eksperimen ialah suatu cara mengajar saat siswa melakukan suatu percobaan tentang sesuatu, mengamati prosesnya, serta menuliskan hasil percobaannya, kemudian hasil pengamatan itu disampaikan ke kelas dan dievaluasi oleh guru.

Berdasarkan definisi tersebut, maka dapat disimpulkan bahwa metode eksperimen bertujuan agar siswa mampu mencari dan menemukan sendiri berbagai jawaban atau persoalan-persoalan yang dihadapinya dengan mengadakan percobaan sendiri. Selain itu siswa juga bisa terlatih dalam cara berpikir yang ilmiah. Dengan eksperimen siswa mampu membuktikan kebenaran dari suatu teori yang sedang dipelajari.

Sebagai metode penyajian, demonstrasi tidak lepas dari penjelasan secara lisan oleh guru. Meskipun dalam proses demonstrasi peran siswa haya sekedar memperhatikan, namun demonstrasi dapat menyajikan bahan pelajaran lebih konkret. Dalam strategi pembelajaran, demonstrasi bisa digunakan untuk mendukung keberhasilan strategi pembelajaran ekspositori dan inkuiri. Penting juga diperhatikan, eksperimen atau percobaan yang dilakukan tidak selalu harus dilaksanakan di dalam laboratorium, tetapi juga dapat dilakukan di luar kelas atau laboratorium. Sebuah eksperimen bisa dilakukan oleh siswa untuk menguji hipotesis suatu masalah, kemudian menarik kesimpulan. Dengan metode eksperimen, siswa diharapkan mampu ikut aktif dan mengambil bagian dalam kegiatan-kegiatan beajar untuk dirinya.

Menurut Arends dalam Abbas (2000), model PBL adalah model pembelajaran dengan pendekatan pembelajaran siswa pada masalah autentik, sehingga ia bisa menyususn pengetahuannya sendiri, menumbuh kembangkan keterampilan yang lebih tinggi, memandirikan siswa, dan meningkatkan kepercayaan diri. Model tersebut bercirikan penggunaan masalah kehidupan nyata sebagai sesuatu yang harus dipelajari oleh siswa untuk melatih dan meningkatkan keterampilan berpikir kritis sekaligus pemecahan masalah, serta mendapatkan pengetahuan konsepkonsep penting. Terkait hal tersebut, guru harus memfokuskan diri untuk membantu siswa mencapai keterampilan mengarahkan diri. Dengan pengertian tersebut, maka model pembelajaran PBL ini bisa digolongkan ke dalam pembelajaran berbasis sains. 


\section{Metode Penelitian}

Populasi dalam penelitian ini adalah siswa kelas X SMA Negeri 4 Madiun tahun pelajaran 2014/2015 yang terdiri dari 8 kelas. Teknik pengambilan sampel dalam penelitian ini menggunakan teknik cluster random sampling. Desain penelitian yang digunakan adalah penelitian eksperimen yang bertujuan untuk mengetahui pengaruh dan interaksi antara suatu variabel terhadap variabel lainnya. Penelitian ini bersifat eksperimental dengan rancangan data penelitian disajikan dalam desain faktorial $2 \times 2 \times 2$ dengan teknik analisis varians (Anava).

Instrumen yang digunakan berupa silabus, RPP dan instrumen pengambilan data berupa tes dan lembar observasi. Instrumen bentuk tes untuk mengukur hasil belajar kognitif, kemampuan berpikir kritis dan kemampuan berpikir kreatif. Instrumen bentuk tes menggunakan tes pilihan ganda untuk soal kognitif dan tes esai untuk tes kemampuan berpikir kritis dan kemampuan berpikir kreatif. Lembar observasi digunakan untuk mengukur hasil belajar afektif dan psikomotorik pada saat penelitian.

Uji validasi instrumen dilakukan oleh ahli sebelum diujicobakan. Setelah uji coba instrumen hasil belajar kognitif, kemampuan berpikir kritis dan keterampilan berpikir kreatif diuji validitas, reliabilitas, taraf kesukaran dan uji daya pembeda soal.

\section{Hasil Penelitian dan Pembahasan}

Uji hipotesis menggunakan uji Anava. Untuk menganalisis data dilakukan dengan SPSS 18. Hasil hipotesis dirangkum dalam Tabel 1.

\begin{tabular}{lllll}
\multicolumn{5}{c}{ Tabel 1. Hasil Uji Hipotesis } \\
\hline No. & $\begin{array}{l}\text { Hipotesis } \\
\text { dengan }\end{array}$ & $\begin{array}{l}\text { Sig. } \\
\text { Kogni-tif }\end{array}$ & $\begin{array}{l}\text { Sig. } \\
\text { Afektif }\end{array}$ & $\begin{array}{l}\text { Sig. } \\
\text { Psiko- } \\
\text { motor }\end{array}$ \\
\hline & ANAVA & & & 0,372 \\
\hline 1. & Hipotesis 1 & 0,974 & 0,876 & 0,070 \\
2. & Hipotesis 2 & 0,088 & 0,199 & 0,777 \\
3. & Hipotesis 3 & 0,003 & 0,598 & 0,348 \\
4. & Hipotesis 4 & 0,655 & 0,951 & 0,659 \\
5. & Hipotesis 5 & 0,834 & 0,510 & 0,585 \\
6. & Hipotesis 6 & 0,909 & 0,822 & 0,166 \\
7. & Hipotesis 7 & 0,654 & 0,424 & \\
\hline
\end{tabular}

Dari hasil analisis anava, jika sig. > 0,05; maka Ho diterima sedangkan jika sig. < 0,05; maka Ho ditolak. Dari Tabel 1 dapat dibahas hipotesis untuk data hasil belajar kognitif, afektif, dan psikomotor sebagai berikut:

1. Hipotesis pertama, pengaruh metode pembelajaran terhadap hasil belajar kognitif, afektif, dan psikomotor.

Berdasarkan hasil keputusan uji disimpulkan bahwa tidak ada pengaruh perbedaan pembelajaran berbasis PBL menggunakan metode eksperimen dan metode demonstrasi terhadap prestasi kognitif, afektif, dan psikomotor. Sehingga hal ini tidak sesuai dengan hipotesis awal yang menyatakan bahwa terdapat pengaruh perbedaan pembelajaran berbasis PBL menggunakan metode eksperimen dan metode demonstrasi terhadap prestasi kognitif, afektif, dan psikomotor.

Dari data tersebut diperoleh bahwa tidak ada perbedaan yang signifikan antara metode pembelajaran dengan hasil belajar siswa. Hal tersebut dipengaruhi oleh beberapa faktor yaitu: Pertama, kedua metode pembelajaran memberikan konstribusi yang baik terhadap pembelajaran fisika terbukti dengan perolehan rata-rata hasil belajar siswa meningkat dari kemapuan awal siswa. Siswa juga terlibat aktif dalam pembelajaran dapat mengembangkan kemampuan dalam mengamati, bereksperimen, dan menghubungkan antara teori serta kenyataan siswa pun dapat melakukan pengujian kesimpulan atau pembuktian kembali konsep yang sudah ditemukan saat melakukan eksperimen. Metode ini dapat membuat pembelajaran semakin jelas dan pengetahuan yang didapat siswa menjadi lebih konkret. Berdasarkan analisis pada dasarnya kedua metode ini memberikan pengaruh positif kepada pembentukan sikap siswa dikarenakan banyaknya terjadi interaksi dengan teman sehingga dapat menumbuhkan nilai kepedulian antar teman sekelompok ataupun berbeda kelompok.

Kedua, materi yang digunakan pada penelitian ini adalah Optika Geometri. Materi ini sangat dekat sekali dengan kehidupan sehari-hari sehingga siswa lebih mudah untuk mempelajari dan mengasumsikan pendapat 
mereka tentang hal-hal yang berhubungan dengan sifat atau manfaat optika geometri. Siswa membutuhkan pemikiran yang imajinatif untuk menyusun sebuah asumsi yang terjadi tentang akibat dan keuntungan adanya Optika Geometri.

Ketiga, respon siswa yang diberikan terhadap kedua metode pembelajaran yang diterapkan adalah sama. Siswa pada kelompok eksperimen antusias dalam melakukan percobaan. Kelompok demonstrasi juga tanggap terhadap permasalahan yang diberikan guru untuk merancang dan menyusun sebuah percobaan. Respon siswa juga berpengaruh besar terhadap hasil belajar yang akan diperoleh siswa setelah pembelajaran. Semakin baik respon siswa terhadap pembelajaran semakin baik pula hasil belajarnya, sebaliknya apabila respon siswa rendah maka akan rendah juga hasil belajar siswa.

Penelitian ini sesuai dengan teori yang dinyatakan menurut Arends dalam Abbas (2000), model PBL adalah model pembelajaran dengan pendekatan pembelajaran siswa pada masalah autentik, sehingga ia bisa menyusun pengetahuan sendiri, menumbuhkembangkan keterampilan yang lebih tinggi dan inkuiri, memandirikan siswa, serta meningkatkan kepercayaan diri.

2. Hipotesis kedua, pengaruh kemampuan berpikir kritis terhadap hasil belajar kognitif, afektif, dan psikomotor.

Berdasarkan hasil keputusan uji disimpulkan bahwa tidak ada pengaruh kemampuan berpikir kritis terhadap hasil belajar kognitif, afektif, dan psikomotor. Hal ini tidak sesuai dengan hipotesis awal yang menyatakan bahwa ada pengaruh kemampuan berpikir kritis terhadap hasil belajar kognitif, afektif, dan psikomotor.

Kemampuan berpikir kritis merupakan salah satu aspek internal yang berpengaruh terhadap prestasi belajar. Pengaruh signifikan yang diberikan antara kemampuan berpikir kritis terhadap hasil belajar kognitif membuktikan bahwa siswa yang memiliki kemampuan berpikir kritis memiliki kemampuan analisis yang baik, dibuktikan dengan nilai rata-rata kemampuan berpikir kritis tinggi sebesar 73,24 dan nilai rata-rata kemampuan berpikir kritis tinggi sebesar. Kemampuan berpikir kritis siswa dapat mempengaruhi daya analisis yang baik untuk menciptakan ataupun menyelsaikan suatu permasalahan.

Liliasari (2005) mengemukakan bahwa berpikir kritis untuk menganalisis argument dan memunculkan wawasan terhadap tiap-tiap makna dan interpretasi, untuk mengembangkan pola penalaran yang kohesif dan logis, memahami asumsi dan bias yang mendasari tiap-tiap posisi. Akhirnya dapat memberikan model presentasi yang dapat dipercaya, ringkas, dan meyakinkan. De Bono (2007) berpendapat bahwa berpikir kritis merupakan suatu keterampilan dalam memilah yang bernilai dari sekian banyak gagasan atau melakukan pertimbangan dari suatu keputusan.

3. Hipotesis ketiga, pengaruh kemampuan berpikir kreatif terhadap hasil belajar kognitif, afektif, dan psikomotor.

Berdasarkan hasil keputusan uji disimpulkan bahwa ada pengaruh kemampuan berpikir kreatif terhadap hasil belajar kognitif. Hal ini sesuai dengan hipotesis awal yang menyatakan bahwa ada pengaruh kemampuan berpikir kreatif terhadap hasil belajar kognitif. Tidak ada pengaruh kemampuan berpikir kreatif terhadap hasil belajar afektif dan psikomotor. Sehingga hal ini tidak sesuai dengan hipotesis awal yang menyatakan bahwa ada pengaruh kemampuan berpikir kreatif terhadap hasil belajar afektif.

Berpikir kreatif merupakan kemampuan untuk melihat bermacam-macam kemungkinan penyelesaian terhadap suatu masalah, merupakan bentuk pemikiran yang sampai saat ini masih kurang mendapat perhatian dalam pendidikan. Orang kreatif tidak memiliki hambatan dalam mempertahankan sikap bermain dengan masalah-masalah yang serius dalam kehidupandan orang kreatif memiliki cara sendiri untuk menyelesaikan permasalahan dengan melihat dampak positif dan negatifnya.

Hasil hipotesis menunjukkan bahwa kemampuan berpikir kreatif berpengaruh terhadap hasil belajar kognitif dikarenakan beberapa faktor yang mempengaruhi hasil 
belajar kognitif, seperti siswa yang memiliki kemampuan berpikir kreatif tinggi cenderung mampu mengingat fakta-fakta, rumus, pengertian dalam materi pembelajaran, dan mampu mengaplikasikan teori dengan kehidupan sehari-hari, sedangkan siswa yang memiliki kemampuan berpikir kreatif rendah cenderung lebih cepat lupa dan tidak mampu mengaplikasikan dalam kehidupan sehari-hari.

Kemampuan berpikir kreatif tidak mempengaruhi hasil belajar afektif dan psikomotor siswa disebabkan karena beberapa hal yaitu saat pembelajaran berlangsung siswa selalu ingin tahu, memiliki minat yang luas, dan menyukai kegemaran dan aktivitas yang kreatif. Siswa sangat mandiri dan memiliki rasa percaya diri yang tinggi. Siswa lebih berani mengambil resiko artinya dalam melakukan eksperimen dan demonstrasi siswa tidak takut membuat kesalahan dan mengemukakan pendapan meskipun banyak teman yang tidak setuju. Rasa percaya diri, keuletan, dan ketekuanan siswa membuat siswa tidak mudah putus asa.

De Bono (2007), menggambarkan harus berpikir kreatif untuk memperbaiki kehidupan, melakukan inovasi desain, menciptakan perubahan dan memperbaiki sistem. Liliasari (2005), mengemukakan bahwa keterampilan berpikir sangat menentukan dalam membangun kepribadian dan pola tindakan dalam kehidupan setiap insan, serta kemampuan berpikir kreatif merupakan salah satu aspek kognitif yang harus diperhatikan dalam proses pembelajaran sains di kelas.

4. Hipotesis keempat, interaksi pembelajaran PBL menggunakan metode eksperimen dan metode demonstrasi dengan kemampuan berpikir kritis terhadap hasil belajar kognitif, afektif, dan psikomotor.

Berdasarkan hasil keputusan disimpulkan bahwa tidak terdapat interaksi pembelajaran berbasis PBL menggunakan metode eksperimen dan metode demonstrasi terhadap hasil belajar afektif, kognitif dan psikomotor. Sehingga hal ini tidak sesuai dengan hasil hipotesis awal yang menyatakan bahwa terdapat interaksi pembelajaran berbasis PBL terhadap hasil belajar kognitif, afektif, dan psikomotor. Hal itu dipengaruhi beberapa faktor.

Pertama, pada hasil belajar kognitif antara metode pembelajar dan kemampuan berpikir kritis merupakan hal yang berdiri sendiri dan tidak berkaitan. Siswa yang memiliki kemampuan berpikir kritis tinggi ataupun rendah tidak memberikan interaksi terhadap metode pembelajaran. Siswa yang memiliki kemampuan berpikir kritis tinggi jika diberi perlakuan dengan metode apapun akan memiliki hasil belajar yang baik begitu sebaliknya.

Kedua, pada hasil belajar afektif interaksi antara metode pembelajaran dan interaksi sosial tidak memberikan pengaruh yang signifikan. Karena siswa yang memiliki kemapuan berpikir kritis tinggi dan rendah mengikuti pembelajaran dengan baik, siswa sama-sama antusias, semangat, dan termotivasi.

Ketiga, pada hasil belajar psikomotor siswa memiliki reaksi natural dalam mengikuti kegiatan pembelajaran untuk menyiapkan presentasi, menyiapkan alat dan bahan dalam praktikum, dan memperhatikan praktikum yang dilakukan. Siswa yang memiliki kemampuan berpikir kritis tinggi dan rendah sama-sama memberikan respon yang baik. Jadi, dapat disimpulkan bahwa tidak ada interaksi antara metode pembelajaran dengan kemampuan berpikir kritis terhadap prestasi belajar kognitif, afektif, dan psikomotor. Siswa yang memiliki kemampuan berpikir kritis tinggi dan rendah akan sama-sama dapat mengikuti pembelajaran dengan baik.

Ibrahim dan Nur (2000), dalam PBL, pemecahan masalah didefinisikan sebagai proses atau upaya untuk mendapatkan suatu penyelesaian tugas atau situasi yang benarbenar nyata sebagai masalah dengan aturanaturan yang sudah diketahui. Jadi, pembelajaran berdasarkan masalah lebih memfokuskan pada masalah kehidupan nyata yang bermakna bagi siswa.

5. Hipotesis kelima, interaksi pembelajaran berbasis PBL menggunakan metode eksperimen dan metode demonstrasi dengan kemampuan berpikir kreatif 
terhadap hasil belajar kognitif, afektif, dan psikomotor.

Berdasarkan hasil keputusan uji disimpulkan bahwa tidak terdapat interaksi pembelajaran berbasis PBL menggunakan metode eksperimen dan metode demonstrasi terhadap hasil belajar kognitif, afektif, dan psikomotor. Hal ini tidak sesuai dengan hasil hipotesis awal yang menyatakan bahwa terdapat interaksi pembelajaran berbasis PBL dengan kemampuan berpikir kreatif terhadap hasil belajar kognitif, afektif, dan psikomotor.

Faktor yang menjadi penyebab tidak adanya interaksi secara statistik antara pembelajaran berbasis PBL terhadap hasil belajar afektif, kognitif, dan psikomotor karena dengan menggunakan metode apapun siswa yang memiliki kemampuan berpikir kreatif tinggi memiliki hasil belajar yang baik, begitu sebaliknya. Kemampuan berpikir kreatif merupakan hal yang dimiliki setiap individu masing-masing dan mereka harus mampu untuk mengeksplorasi kemampuan berpikir kreatif. Jika ada siswa yang mamiliki nilai kemampuan berpikir kreatif tinggi tetapi tidak dapat mengeksplorasi akan berakibat penurunan pada hasil belajar siswa.

Siswono dalam penelitian Supardi (2012) menyatakan bahwa meningkatkan kemampuan berpikir kreatif artinya maikan skor kemampuan siswa dalam memahami masalah, kefasihan, fleksibilitas, dan kebaruan penyelesaian masalah. Siswa dikatakan memahami masalah bila menunjukkan apa yang diketahui dan apa yang ditanyakan, siswa memiliki kefasihan dalam menyelesaikan masalah bila dapat menyelesaikan masalah dengan jawaban bermacam-macam yang benar secara logika. Siswa memiliki fleksibilitas dalam menyelesaikan masalah bila dapat menyelesaikan masalah bila dapat menyelesaikan soal dengan dua cara atau lebih yang berbeda dan benar. Siswa memiliki kebaruan dalam menyelesaika masalah bila dapat membuat jawaban yang berbeda dari jawaban sebelumnya atau yang umum diketahui siswa.

6. Hipotesis keenam, kemampuan berpikir kritis dengan kemampuan berpikir kreatif terhadap hasil belajar kognitif, afektif dan psikomotor.

Berdasarkan hasil keputusan uji disimpulkan bahwa tidak ada interaksi kemampuan berpikir kritis dengan kemampuan berpikir kreatif terhadap hasil belajar kognitif, afektif, dan psikomotor.

Tidak adanya interaksi ini antara kemampuan berpikir kritis dengan kemampuan berpikir kreatif siswa disebabkan karena kemampuan berpikir kritis dan kemampuan berpikir kreatif adalah dua hal yang berbeda dan tidak saling berhubungan. Namun, kedua kemampuan berpikir tersebut dapat mempengaruhi hasil belajar siswa baik kognitif, afektif, ataupun psikomotor.

Kemampuan berpikir kritis merupakan kemampuan berpikir siswa yang mengaktifkan ketelitian dalam penyelesaian masalah tanpa mendatangkan langsung objek dari permasalahan tersebut. Sedangkan kemampuan berpikir kreatif merupakan kemampuan siswa untuk menyelesaikan suatu permasalah dengan ide-ide baru yang tidak lazim sehingga ditemukan cara baru dalam penyelesaian suatu permasalah.

Wijaya (2007) menyatakan bahwa berpikir kritis adalah suatu kegiatan atau proses menganalisis, menjelaskan, mengembangkan, atau menyeleksi ide, mencakup mengkategorikan, menguji argumentasi dan asumsi, serta mengevaluasi kesimpulan.

7. Hipotesis ketujuh, interaksi metode pembelajaran, kemampuan berpikir kritis dan kemampuan berpikir kreatif

Siswa yang memiliki kemampuan berpikir kritis tinggi tidak diimbangi dengan sikap ilmiah tinggi maka akan memiliki nilai yang kurang baik. Tetapi pada hipotesis ini ketika keduanya berinteraksi, siswa yang memiliki kemampuan berpikir kritis tinggi ataupun siswa yang memiliki kemampuan berpikir kritis rendah ataupun sebaliknya, hal ini tidak dapat diprediksi dengan pasti. Karena berdasarkan analisis diperoleh hasil rata-rata yang signifikan.

Menurut pengamatan di lapangan siswa yang memiliki kemampuan berpikir kritis tinggi maupun rendah serta kemampuan 
berpikir kreatif tinggi ataupun rendah akan sama-sama dapat mengikuti pembelajaran dengan baik. Semua siswa datang dengan tepat waktu dan melakukan pembelajaran dengan baik. Siswa antusias dalam mengikuti pembelajaran Pada kelas demonstrasi siswa memilki rata-rata hasil belajar yang baik dibandingkan dengan kelas ekperimen. Pembelajaran pada kelas demonstrasi yang menekankan kemandirian pada siswa membuat siswa lebih memaknai proses pembelajaran.

Siswa yang memiliki kemampuan befikir kritis tinggi memiliki hasil belajar yang lebih baik daripada siswa yang memiliki kemampuan berpikir kritis rendah. Siswa yang memilki kemampuan berpikir kreatif juga memilki hasil belajar yang baik dibandingkan siswa yang memilki kemapuan berpikir kreatif rendah. dari hal tersebut dapat disimpulkan bahwa kemampuan berpikir kreatif siswa sangat mempengaruhi keberhasilan dalam belajar mereka.

Hal ini tidak sesuai dengan hipotesis awal yang menyebutkan terdapat interaksi pembelajaran PBL menggunakan metode eksperimen dan metode demonstrasi dengan kemampuan berpikir kritis dan kemampuan berpikir kreatif terhadap hasil belajar siswa. Hal ini disebabkan faktor baik internal maupun eksternal dari dalam diri siswa yang dapat mempengaruhi siswa untuk mendapatkan hasil belajar yang baik. Faktor-faktor tersebut meliputi pendekatan pembelajaran, metode pembelajaran, kemampuan berpikir kritis dan kemampuan berpikir kreatif siswa, serta masih banyak keterbatasan dalam penelitian sehingga tidak dapat mengontrol faktor-faktor diluar kegiatan pembelajaran.

Pada penelitian yang dilakukan Wang (2012) mengatakan bahwa Pembelajaran berbasis masalah (PBL) dianggap sebagai pendekatan instruksi yang berpusat pada siswa dimana terinspirasi siswa untuk menerapkan berpikir kritis melalui masalah simulasi multifaktor dan masalah rumit yang mungkin memiliki atau memiliki jawaban yang standart.

\section{Kesimpulan dan Rekomendasi}

Hasil penelitian ini dapat disimpulkan: 1) tidak terdapat pengaruh pembelajaran $\mathrm{PBL}$ menggunakan metode eksperimen dan metode demonstrasi terhadap hasil belajar siswa. Pembelajaran PBL menggunakan metode eksperimen dan metode demonstrasi memberikan pengaruh yang sama baik terhadap hasil belajar siswa; 2) tidak terdapat pengaruh kemampuan berpikir kritis terhadap hasil belajar kognitif, afektif dan psikomotor. Kemampua berpikir kritis tidak memberikan perngaruh terhadap hasil belajar kognitif, afektif, dan psikomotor; 3) terdapat pengaruh kemampuan berpikir kreatif terhadap hasil belajar kognitif. Tidak terdapat perbedaan pengaruh kemampuan berpikir kreatif terhadap hasil belajar afektif dan psikomotor signifikan. Kemampuan berpikir kreatif memberikan pengaruh terhadap hasil belajar kognitif siswa tetapi tidak mempengaruhi hasil belajar afektif dan psikomotor; 4) tidak terdapat pengaruh interaksi metode pembelajaran terhadap kemampuan berpikir kritis signifikan kognitif, afektif, dan psikomotor. Metode pembelajaran dan kemampuan berpikir kritis merupakan hal yang berbeda. Sehingga siswa yang memiliki kemampuan berpikir kritis tinggi memiliki hasil belajar tinggi sedangkan siswa yang memiliki kemampuan berpikir kritis rendah memiliki hasil belajar rendah. Jadi, dapat disimpulkan bahwa kemampuan berpikir kritis tidak berpengaruh terhadap hasil belajar siswa; 5) tidak terdapat pengaruh interaksi metode pembelajaran dan kemampuan berpikir kreatif. Kemampuan berpikir kreatif tidak berpengaruh terhadap hasil belajar karena siswa yang memiliki kemampuan berpikir kreatif tinggi akan memperoleh hasil belajar tinggi sedangkan siswa yang memiliki kemampuan berpikir kreatif rendah memperoleh hasil belajar rendah; 6) tidak terdapat pengaruh interaksi kemampuan berpikir kritis dan kemampuan berpikir kreatif. Kemampuan berpikir kritis dan kemampuan berpikir kreatif sama-sama berpengaruh terhadap hasil belajar siswa. Kedua kemampuan berpikir ini sangat diperlukan untuk menganalisis hal-hal yang bersifat kritis; 7) tidak terdapat pengaruh 
interaksi metode pembelajaran, kemampuan berpikir kritis dan kemampuan berpikir kreatif. Antara metode dan kemampuan berpikir merupakan dua hal yang berbeda sehingga tidak diperoleh interaksi yang signifikan. Jadi, siswa yang memiliki kemampuan berpikir kritis dan kreatif tinggi akan memperoleh hasil belajar yang tinggi pula meskipun diberi pembelajaran dengan metode apapun, begitu juga sebaliknya siswa yang memiliki kemampuan berpikir kritis dan kreatif rendah akan memperoleh hasil belajar yang rendah pula.

Dalam rangka turut menyumbangkan pemikiran yang berkenaan dengan peningkatan hasil belajar fisika disarankan kepada tenaga pendidik perlu mempersiapkan secara matang perangkat pembelajaran yang sesuai dengan pembelajaran. Kepada siswa dapat meningkatkan kemampuan berpikir kritis dan kemampuan berpikir kreatif sehingga dapat mempermudah memahami materi pelajaran, membentuk kerjasama yang baik, dan saling membantu antar anggota kelompok dalam memecahkan suatu masalah.

\section{Daftar Pustaka}

Abbas, Nurhayatin. (2000). Pengembangan Perangkat Pembelajaran Matematika Berorientasi Model Pembelajaran Berbasis Masalah (Problem Based Instruction). Program Studi Pendidikan Matematika Pasca Sarjana. Surabaya: UNESA

Ali, Muhammad. (2000). Guru Dalam Proses Belajar Mengajar . Bandung: Sinar Baru Algesindo

De Bono, E. (2007). Revolusi Berpikir. Bandung: Mizan Media Utama

Depdiknas. (2004). Petunjuk Pelaksaan dan Pengelolaan Kurikulum. Jakarta: Depdiknas

Djamarah,S.B. (2000). Guru dan Anak Didik dalam Interaksi Edukatif. Jakarta: Rineka Cipta

Ibrahim dan Nur. (2000). Pembelajaran Berbasis Masalah. Surabaya: UNESA

Liliasari. (2005). Membangun Keterampilan Berpikir Manusia Indonesia Melalui
Pendidikan Sains. Pidato Pengukuhan Guru Besar Tetap dalam Ilmu Pendidikan IPA. Universitas Pendidikan Indonesia

Munadar, Utami. (2002). Kreativtas dan Keberbakatan Strategi Mewujudkan Potendi Kreatif dan Bakat. Jakarta: Gramedia Pustaka

Putra, S. R. (2013). Desain Belajar Mengajar Kreatif Berbass Sains. Jogjakarta: Diva Press

Rusman. (2010). Model-Model Pembelajaran. Bandung: Raja Grafindo Persada

(2012). Model-Model Pembelajaran Mengembangkan Profesional Guru. Bandung: Raja Grafindo Persada

Roestiyah. (2001). Strategi Belajar Mengajar. Jakarta: Rineka Cipta

Sagala, Syaiful. (2007). Manajemen Strategi dalam Peningkatan Mutu Pendidikan. Bandung: Alfabeta

Sudirman. (1991). Ilmu Pndidikan. Bandung: Remaja Rosdakarya

Sudjana, Nana. (2000). Dasar-Dasar Proses Belajar Mengajar. Jakarta: Sinar Baru Algesindo

Sugiarti, Piping, (2005).Penerapan Teori Multiple Intellegence dalam Pembelajaran Fisika. Jurnal Pendidikan Penabur. 4(5)

Supardi. (2012). Peran Berpikir Kreatif Daalam Proses Pembelajaran Matematika. Jurnal Formatif. 2(3): 248-262

Syah, Muhibbin. (2010). Psikologi Pendidikan dengan Pendekatan Baru. Bandung: Remaja Rosda Karya

Trianto. (2009). Mendesain Model Pembelajaran Inovatif-Agresif. Jakarta: Kencana Prenada Media Grup

(2010). Model-Model Pembelajaran Inovatif-Progresif. Jakarta: Kencana

Wang, Tzu pu. (2012). Applying ProblemBasedLearnig (PBL) in University English Traslation Clases. The Journak of International Management Studies.7(1).

Wijaya, Cece. (2007). Sarana Pengembangan Mutu Sumber Daya Manusia. Bandung: Remaja Rosdakarya. 
JURNAL INKUIRI

ISSN: 2252-7893, Vol. 6, No. 3, 2017 (hal 49-60)

http://jurnal.uns.ac.id/inkuiri 